2021, Volume 16, ATEE 2020 - Winter Conference. Teacher Education for Promoting WellBeing in School. Suceava, 2020, pages: $455-471$ |

\section{Parental Education and the Need to Train Parents in 21 st Century}

\section{Andreea ŞIT, OIU ${ }^{1}$}

${ }^{1}$ Assistant professor, Faculty of Psychology and Educational Sciences, Transilvania University. andreea.sitoiu@unitbv.ro
Abstract: The challenges of the 21st century impose on today's parent the need to take part in a new type of education, namely, parental education. This type of education takes into account the discipline of the parent, by providing relevant information on: the characteristics of children according to their age, parental typologies with the advantages and disadvantages of each, parenting strategies that ensure streamlining the parent-child relationship, as well as the obstacles encountered in the process of raising and educating the child.

The multitude of information stated above, arouses the interest for training parents in the field of parenting, but also the need to implement training programs with a central theme, parental education.

Following the application of a focus group interview, which was attended by eight parents whose children are part of primary school, it was found that they are aware of the shortcomings they have, but also of the mistakes they make as parents, concluding that a training program in the field of parental education would be a real guide for parenting.

In agreement with the current society, a technological society, it is necessary to design and implement a training program that aims, on the one hand: issues related to parenting, on the other hand, issues related to technological resources, establishing the following objectives: to make some correspondences between the particularities of the children and the parental practices, in the technological era; streamlining the parent-child relationship in the digital age; openness to the use of digital tools; providing the necessary resources for an optimal adaptation of the parent to the digital age.

Keywords: parental education; training program; parent-child relationship; technological society; parent adaptation.

How to cite: Şițoiu, A. (2021). Parental Education and the Need to Train Parents in 21st Century. In O. Clipa (vol. ed.), Lumen Proceedings: Vol. 16. ATEE 2020 - Winter Conference.

Teacher Education for Promoting Well-Being in School. Suceava, 2020 (pp. 455-471). Iasi, Romania: LUMEN Publishing House. https://doi.org/10.18662/lumproc/atee2020/32 


\section{Introduction}

\subsection{The chapter of introduction}

Parenting, according to Alfie Kohn (2013, 2017), Gottman (2018), Ginott (2018), Gordon (2014), respectively Siegel \& Bryson (2019), refers to: parent-child communication style, how to make of the decision by involving or not involving the child in its choice, respectively the independence granted to the child by his parent.

Alfie Kohn (2017), is a follower of the idea that parenting involves understanding, listening, patience, but also guidance, being aware that there are times when parents do not have the time or emotional readiness to do all this leisurely.

Gottman (2018) considers that effective parenting is one that is based on a lot of empathy. The argument is that the empathic parent is perceived by the child as an ally.

The education of 21 st century parents, parents belonging to a technological society, aims at a paradigm shift, representing the transition from parenting based on conditional love to permissive parenting, which focuses on raising and educating the child by imposing healthy boundaries and adapting parental authority to the needs of the child.

\subsection{The research gap}

\section{1st century parenting barriers to effective parenting}

Parental nervousness

Haim Ginott (2018), proposes to parents three steps, called survival steps, to help them in times of feelings of anger and nervousness. children.

1. We accept that we sometimes get angry when dealing with

2. We have the right to be angry without guilt or shame.

3. On one condition, we are entitled to express what we feel. We can express our feelings of anger as long as we do not attack the child's personality or character. " (Ginott, 2018, p. 55)

Conditional love

Psychologist Carl Rogers found an answer to the question "What happens when parental love depends on what the child does?" He claims that in this situation, the child ends up denying those sides that are not appreciated. They will feel loved only when they adopt certain behaviors or attitudes that they know are to their parents' liking. The feeling of love, approached in such a way, opens the way to neurosis for the child, and self- 
esteem in this case will be even lower as the support provided to the child is more conditioned.

\section{Excessive self-discipline}

Self-discipline refers to the use of the will in order to achieve desirable behavior. Self-control involves the application of the same kind of will to prevent action in an undesirable way.

Self-discipline is effective when it is characterized by flexibility and moderation. Thus, children need to acquire the ability to be flexible and moderate and not to over-self-discipline and self-control. (Kohn, 2017)

There is a myth that if you force a child to do certain things, he will become responsible and disciplined. Some children may be subjected to such severity, but in the future they will need an authority to control their behavior. These children will become adults without the capacity for selfdiscipline, to take responsibility for certain deeds because they have never been given the opportunity to cultivate such qualities. (Gordon, 2014)

\section{Low self-esteem of parents}

Parents who meet their needs through independent efforts, accept themselves and do not feel the need to find the satisfaction of their needs through the behavior of children, reaching to show tolerance towards their children. On the other hand, those parents who have low self-esteem and satisfaction come from the way other people appreciate their children, tend to become intolerant of them. (Gordon, 2014)

\section{Non-acceptance of children by parents}

In a study on parenting styles and self-esteem conducted on a sample of 540 students, 240 girls and 306 boys, the following aspects were demonstrated: those parents who manifested in the relationship with their own children, the attitude of acceptance to the detriment of excessive control, determined a better self-esteem of the children. (Zakeri \& Karimpour, 2011)

\section{Parents' reactions to their children's behavior}

In addition to the multitude of skills that parents must demonstrate in raising and educating a child, it is necessary to know and interpret the emotions he experiences. Children want their parents to discover what is in their soul, although they bring to the surface only a small part of the emotions and feelings they experience. Instead of reacting to the child's behavior, parents should respond to their feelings of fear, despair, helplessness. Such an attitude would help children to feel safe, to think clearly and of course to find a solution to solve problems.

Although many parents have been taught that negative feelings are harmful, this mentality should not be passed on to their children. A child's behavior should be praised or criticized and not the child's feeling or fantasy. 
Judging feelings and censoring fantasy impedes the child's freedom and mental health. (Ginott, 2018)

In the field of parenting, it is useful to distinguish between intrinsic and extrinsic motivation when it comes to certain actions or behaviors that the child adopts. Just because motivation is a process that takes place within the human being does not necessarily mean that it is intrinsic. If a child is controlled by his parents, he is subject to rewards and punishments, but this time, they become part of the child's structure. He knows that when he behaves desirably, he will be rewarded, and this reward gives him a good sense of self, even though it is temporary. Conversely, if you exhibit undesirable behavior, your sense of self will be awful. This form of internalization, which can easily be confused with intrinsic motivation, is the consequence of conditioned self-esteem.

The result of such internalization materializes in the education of confused children, unhappy with less chance of success. Although the reason they do something is internal, they do not feel it comes naturally. In such a situation, the child may suffer from what psychoanalyst Karen Horney called "his tyranny must." Children end up not knowing what they really want or who they really are.

When a child experiences the feeling that he "must" have a certain type of behavior, his emotions, to some extent, will be disturbed, he will no longer be able to control them, but will emerge in a way that is difficult to control (Ginott, 2018).

In a study of 180 children who investigated the effect of apologizing for children's emotions, it was found that when a child is apologized for, his or her positive emotions increase over time. what negative emotions diminish, the final effect being that of stimulating the self-confident attitude (Fengling et al., 2018).

\section{The parent of the 21st century and the age of technology}

With the advancement of digital resources, parents today have a new responsibility, namely to teach the child to resist distraction, as a result of the technology he uses (Palladino, 2015).

A beneficial attitude on the part of parents to meet the challenges of the digital age is to create a habit of talking to their children about technology, similar to that in which parent-child communication is based on issues related to school work. This habit facilitates mediation in the use of digital resources and will lead the child to trust his parent. It is well known that the relationship based on trust is essential in many ways, including parenting and involvement in online life (Chaudron, Gioia, \& Gem, 2018).

Following a study on technology, the following formative effects of its use by children were presented: 
1. Children improve their motor skills by using various tools that mediate digital activity: keyboard, mouse.

2. Children develop their cognitive abilities through multiple educational applications and games;

3. Technology is an important source of entertainment for today's children (Sundus, 2018);

Parents' rigidity in the use of technology can be a consequence of their inability to manage the time and types of information to which the child is exposed through the use of technology (Stan, 2016).

The attitude of rigidity from this point of view, will not ensure the well-being of the child, therefore the adult of the XXI century is challenged to redefine his structure as a parent to streamline parenting strategies, but also to cope with the era. digitized.

Recommendations for parents regarding the use of technology were also offered following a study on the effects of digital resources on children. These are the following:

1. Parents should have as many discussions as possible with their children so that they do not feel restricted;

2. Parents should constantly monitor the reasons why their children use digital resources;

3. Young children should use the technology for no more than one hour a day and for educational purposes only;

4. As the use of digital resources is inevitable nowadays, parents should impose limits on their use;

5. The use of technology for educational purposes should be encouraged;

6. Parents should provide their children with explanations about the difference between the real and virtual elements of their lives specific to the online environment (Xavier, 2015).

\section{Research questions/Aims of the research}

The aim of this research is to identify the particularities of parents' education, specific to the 21 st century and at the same time to design a training program based on the effective parent-child relationship, mediated by the use of technology.

The research approach starts from the following questions:

1. What are the central themes specific to parenting, studied in the literature?

2. How is parental education promoted in the virtual environment? 


\section{Research objectives} education

1. The analysis of the specialized literature specific to the parents'

2. Identifying the main concepts related to parental education, encountered in the virtual environment.

\section{Research hypotheses}

1. The specialized literature adapts the specific elements of the parents' education to the current society.

2. The informational resources in the virtual environment provide an overview of parents' education, in accordance with the literature specific to the field.

\section{Research methods}

\subsection{Participants}

This research does not involve collecting data through human resources, but only through material resources, which consist of specialized books, respectively information resources from the online environment. Starting from these material resources, a training program dedicated to the parents of the 21 st century will be implemented.

\subsection{Materials and instruments}

To start this research, the thematic analysis of specialized books and the analysis of documents were used.

The thematic analysis of specialized books is based on the analysis of 9 books in the field of parental education.

The analysis of the documents is based on the following virtual educational resources: the facebook page "Tikaboo" Romania and the educational website "7 years at home".

\subsection{Procedure}

The thematic analysis of the specialized books aims to identify the main concepts specific to parents' education, found in nine books specific to this field.

"Tikaboo" Romania facebook page was analyzed during three months, between November 1, 2019 and January 31, 2020. During this time, a monitoring of the articles posted every day, the average frequency of posting per day was performed. being of four articles. After noting the title of each article, the articles with the highest posting frequency were identified, formulating themes and sub-themes. 
The educational site "7 years at home" was analyzed in February 2020. Unlike the analysis of the facebook page "Tikaboo" Romania, which targeted the articles posted during three months, for this educational site, they all existing articles were analyzed, these being structured on months, during a year, and the frequency of posting is two or three articles per month. After noting the title of each article, the articles with the highest posting frequency were identified, formulating themes and sub-themes.

\section{Results}

To test the first hypothesis, according to which, the literature adapts the specific elements of parental education, to the current society, the content of nine specialized books in the field of parental education was analyzed. Following this analysis, the main topics covered are: rethinking the discipline, positive education, parent-child connection, emotional health, unconditional parenting, and parental authority.

\begin{tabular}{c|c}
\hline $\begin{array}{c}\text { The concept specific to the } \\
\text { field of parental education }\end{array}$ & $\begin{array}{c}\text { The specialized literature that analyzes the } \\
\text { respective concept }\end{array}$ \\
\hline \multirow{5}{*}{ Rethinking discipline } & $\begin{array}{c}\text { Siegel, D., Bryson, T.P. Parental intelligence } \\
\mathbf{( 2 0 1 9 ) , ~ K o h n , ~ A . ~ T h e ~ m y t h ~ o f ~ t h e ~ s p o i l e d ~ c h i l d ~} \\
(2017), \text { Gordon, T. The effective parent (2014), } \\
\text { Bedard N. How do we behave with children } \\
\text { according to their temperament? (2015), Kohn, } \\
\text { A. Unconditional parenting (2013), Gottman, J. } \\
\text { Parenting. How to raise emotionally intelligent } \\
\text { children (2018), Ginott, H. Between parent and } \\
\text { child (2018), Chapman, G. \& Campbell, R. The } \\
\text { five languages of children's love (2018), Ziglar, } \\
\text { Z. We can raise good children in a negative } \\
\text { world (2019). }\end{array}$ \\
\hline Positive education & $\begin{array}{c}\text { Gordon, T. The effective parent (2014), Kohn, A. } \\
\text { Unconditional parenting (2013), Ginott, H. } \\
\text { Between parent and child (2018), Ziglar, Z. We } \\
\text { can raise good children in a negative world } \\
\text { (2019). }\end{array}$ \\
\hline
\end{tabular}


Siegel, D., Bryson, T. P. Parental intelligence (2019), Gordon, T. The effective parent (2014),

Bedard N. How do we behave with children according to their temperament? (2015), Parent-child connection Gottman, J. Parenting. How to raise emotionally intelligent children (2018), Chapman, G. \& Campbell, $R$. The five languages of children's love (2018), Ziglar, Z. We can raise good children in a negative world (2019).

\begin{tabular}{c|c}
\hline \multirow{3}{*}{ Emotional health } & Siegel, D., Bryson, T. P. Parental intelligence \\
& (2019), Kohn, A. Myth of the spoiled child \\
& (2017), Kohn, A. Unconditional parenting (2013). \\
Siegel, D., Bryson, T.P. Parental intelligence \\
(2019), Kohn, A. The myth of the spoiled child \\
(2017), Gordon, T. The effective parent (2014), \\
Bedard N. How do we behave with children \\
according to their temperament? (2015), Kohn, \\
A. Unconditional parenting (2013), Gottman, J. \\
Parenting. How to raise emotionally intelligent \\
children (2018), Ginott, H. Between parent and \\
child (2018), Chapman, G. \& Campbell, R. The \\
five languages of children's love (2018), Ziglar, \\
Z. We can raise good children in a negative \\
world (2019). \\
\hline Siegel, D., Bryson, T.P. Parental Intelligence \\
(2019), Gordon, T. The Effective Parent (2014), \\
Ginott, H. Between Parent and Child (2018), \\
Gottman, J. Parenting, How to Grow \\
Emotionally Intelligent Children (2018), \\
Chapman, G. \& Campbell, R. The five languages \\
of children's love (2018)
\end{tabular}

Source: Authors own contribution

All these themes specific to parental education correspond to today's society, a society that advocates the adoption of unconditional parenting, based on mutual respect, unconditional love and support. Thus, the hypothesis is confirmed, the literature adapts the specific elements of parents' education to today's society.

To test the hypothesis that the information resources in the virtual environment provide an overview of parental education, in accordance with the literature specific to the field, were analyzed the contents of virtual resources, namely, the facebook page "Tikaboo" Romania and the educational site "7 years at home". Also, the literature in the field of parent education, which awakens 
topics such as positive education, parent-child relationship, specific issues of unconditional parenting, as well as the two resources analyzed, discusses the following main topics: effective parenting, parent-child relationship, and parent adaptation to the needs of his child. It is found that although the information is presented in the virtual environment, a more difficult environment to control in terms of information dissemination, they coincide with the trends inspired by the contents of the literature, thus confirming the hypothesis that information resources in the virtual environment provide an overview of parents' education, in accordance with the field-specific literature.

\begin{tabular}{|c|c|c|c|c|c|}
\hline $\begin{array}{l}\text { Nr. } \\
\text { No. }\end{array}$ & Period & $\begin{array}{l}\text { The name } \\
\text { of the } \\
\text { analyzed } \\
\text { virtual } \\
\text { resource }\end{array}$ & Theme & Subtopic & Frequency \\
\hline \multirow[t]{2}{*}{1} & $\begin{array}{c}\text { November } \\
2019- \\
\text { January } \\
2020\end{array}$ & $\begin{array}{l}\text { "Tikaboo" } \\
\text { Romania }\end{array}$ & \multirow[t]{2}{*}{$\begin{array}{l}\text { Efficient } \\
\text { parenting }\end{array}$} & $\begin{array}{c}\text { Unconditional } \\
\text { love } \\
\text { Emotional } \\
\text { intelligence } \\
\text { Setting } \\
\text { boundaries } \\
\text { Development } \\
\text { of self-control }\end{array}$ & 10 articles \\
\hline & $\begin{array}{c}\text { February } \\
2020\end{array}$ & $\begin{array}{c}\text { "7 years at } \\
\text { home" }\end{array}$ & & $\begin{array}{l}\text { Parent's courage } \\
\text { to be lenient } \\
\text { The conscious } \\
\text { father } \\
\text { Expressing love } \\
\text { for the child }\end{array}$ & 7 articles \\
\hline 2 & $\begin{array}{c}\text { February } \\
2020\end{array}$ & $\begin{array}{l}\text { "7 years at } \\
\text { home" }\end{array}$ & $\begin{array}{l}\text { Parent-child } \\
\text { relationship }\end{array}$ & & \\
\hline
\end{tabular}


Source: Authors own contribution

\begin{tabular}{|c|c|c|c|c|c|}
\hline \multirow{4}{*}{2} & $\begin{array}{l}\text { November } \\
\text { 2019- } \\
\text { January } \\
2020\end{array}$ & $\begin{array}{l}\text { "Tikaboo" } \\
\text { Romania }\end{array}$ & \multirow{4}{*}{$\begin{array}{l}\text { Parent-child } \\
\text { relationship }\end{array}$} & $\begin{array}{c}\text { Parent-child } \\
\text { communication } \\
\text { (communication } \\
\text { based on }\end{array}$ & \\
\hline & \multirow[t]{3}{*}{$\begin{array}{l}\text { February } \\
2020\end{array}$} & \multirow[t]{3}{*}{$\begin{array}{c}\text { "7 years at } \\
\text { home" }\end{array}$} & & $\begin{array}{l}\text { messages) } \\
\text { Development } \\
\text { of self-control } \\
\text { The friendship } \\
\text { between parent } \\
\text { and child } \\
\text { The need to } \\
\text { love the child }\end{array}$ & 5 articles \\
\hline & & & & $\begin{array}{c}\text { Awareness of } \\
\text { the child's } \\
\text { feelings }\end{array}$ & \multirow[b]{2}{*}{4 articles } \\
\hline & & & & $\begin{array}{l}\text { Visual contact } \\
\text { in the parent- } \\
\text { child } \\
\text { relationship }\end{array}$ & \\
\hline \multirow[t]{4}{*}{3} & $\begin{array}{l}\text { November } \\
\text { 2019- } \\
\text { January } \\
2020\end{array}$ & $\begin{array}{l}\text { "Tikaboo" } \\
\text { Romania }\end{array}$ & \multirow{4}{*}{$\begin{array}{l}\text { Adapting } \\
\text { parents to the } \\
\text { needs of the } \\
\text { child }\end{array}$} & $\begin{array}{l}\text { Training the } \\
\text { child's skills } \\
\text { Alternatives to } \\
\text { criticizing the } \\
\text { child } \\
\text { Parent-child } \\
\text { connection }\end{array}$ & 8 articles \\
\hline & \multirow{3}{*}{$\begin{array}{c}\text { February } \\
2020\end{array}$} & \multirow{3}{*}{$\begin{array}{c}\text { "7 years at } \\
\text { home" }\end{array}$} & & Child safety & \multirow{3}{*}{$\begin{array}{c}12 \\
\text { articles }\end{array}$} \\
\hline & & & & $\begin{array}{c}\text { Discipline } \\
\text { unhealthy habits }\end{array}$ & \\
\hline & & & & $\begin{array}{l}\text { Respect for } \\
\text { children }\end{array}$ & \\
\hline
\end{tabular}

The results obtained from the implementation of the two research methods, highlight the need to design and implement a training program specific to parents' education, offering them the opportunity to find the most appropriate strategies to adapt to their children's needs and thus educate them, according current society. The training program envisages activities that combine notions specific to child psychology and parenting in general with notions specific to the field of technology, in order to create a parent-child partnership in terms of digital resources. Such a partnership aims at adapting to the needs of the child, the effective parent-child relationship, through digital tools, pleasant to children and generally used by 
them, as well as providing favorable contexts for parents in order to develop a open minded about technology.

The training program will be called "Challenges of the parent-child relationship in the technological age" skills:

Through this training program, students will have the following

1. Adaptation to the age peculiarities of the child;

2. The ability to relate to one's own child, in the context of the technological society;

3. Use of technological resources to improve the parent-child relationship;

4. Ability to become the child's partner in the digital learning process.

The needs analysis was carried out through an indirect survey based on a questionnaire aimed at adapting parents to the technological age. This questionnaire was answered by 100 parents, and based on the answers provided, the following training needs were identified: children;

1. Knowledge of the particularities specific to the age of their

2. Adapting parental practices to the age peculiarities of children;

3. Valorization of technological resources in the parent-child relationship.

The objectives of this training program are the following:

1. Making correspondences between the particularities of children and parental practices, in the technological age;

2. Streamlining the parent-child relationship in the technological age;

3. Openness to the use of digital tools;

4. Ensuring the necessary resources for an optimal adaptation of the parent to the technological era.

The training program is structured in the form of deductive alternation, starting from theoretical elements and continuing with practical elements. Within the deductive alternation, there will be a sequence of the training program, which will be done in the form of remote individualization. Individualization consists in the design of activities by the parent, in partnership with his child, based on the information discussed during the plenary sessions, laboratories and workshops.

Of all the components of a training program, this article will present the activities designed based on the needs analysis, the skills to be trained, the general objectives. 
Theme 1 (common theme): Psychology of ages - a useful tool in the parenting profession

Objective: At the end of the internship, students will be able to adapt to the age-specific features of their child

Detailing the contents: Students will participate in a plenary session based on elements essential to the psychology of ages. Aspects such as: physical, cognitive and socio-emotional development, in general with the related educational implications, will be considered.

\section{children}

Theme 2 (optional theme): Ways to optimize the parent's relationship with his

Objective: At the end of the training stage, students will demonstrate their ability to use strategies to remedy the parent-child relationship.

Detailing the contents: For this option, the activity will take place in the form of a laboratory. Three distinct laboratories will be organized: a laboratory for parents whose children are in primary school, a laboratory for parents whose children are in middle school and a laboratory for parents whose children are in high school. Parents will be organized into groups for this lab, so as to discover features specific to their relationships with their own children and to share experiences from the parent-child relationship.

Theme 3 (common theme): The impact of technology on new generations

Objective: At the end of the internship, students will be able to manage the impact that technology has on a child's development.

Detailing the contents: Aspects related to the impact of technology on the physical, social, emotional and cognitive development of the child, with implications on the parent-child relationship, will be discussed.

\section{Theme 4 (common theme): The characteristics of a suitable digital resource}

Objective: At the end of the training course, students will demonstrate the ability to use strategies to avoid the harmful effects of technology.

Content details: The criteria that technological tools must meet in order to be suitable for children's use will be presented: to be educational, to encourage collaboration, to support integration (we do not provide access to technology as a recommendation), to involve play, to provide the possibility for the child to control the applications, the game (it is recommended that digital resources do not control the child, but vice versa), to be transparent and intuitive, the applications have clearly and intuitively defined functions and each task performed in the virtual environment to be performed through a single operation), to avoid violence and stereotypes, to support the development of awareness of health and safety issues (integrating 
technology with a series of practical activities, which involve movement and exercise), to support parental involvement.

In a laboratory, based on the theoretical aspects discussed in the plenary session, students will have at their disposal several digital resources (digital lesson, educational site, game, cartoon, educational games) that they will analyze starting from the features discussed in the plenary session.

\section{Theme 5 (common theme): Computer learning and digital platforms}

Objective: At the end of the training program, students will identify the implications that technology has on learning.

Detailing the contents: Theoretical aspects about computer learning will be discussed, which should arouse the interest of parents for such learning and determine them to understand the reasons why technology is really useful especially in learning activities.

Students will participate in a laboratory, where they will be taught how to work with an online platform, more precisely at the end of this activity, they will be able to:

* browse an educational platform;

* to open the learning resources, uploaded on the platform;

* upload materials to the platform for evaluation

\section{Theme 6 (common theme): Ways of working with digital applications}

Objective: At the end of the training program, students will be able to work with classic digital applications: Microsoft Word, Microsoft Powerpoint, Microsoft Publisher

Content details: The trainer introduces students to the ways of working with these applications, guides parents in doing exercises, for example: writing texts in Microsoft Word, making simple presentations in Microsoft Powerpoint, based on the insertion of images and writing texts, or creating concept maps or interactive layouts in Microsoft Publisher. All these contents will contribute to the efficiency of the parent-child relationship and to the parent's awareness of the need and benefits of technology.

Following these contents, the parent will be able to be more involved in his child's school tasks, will be able to initiate interactive play activities, which will combine the interest for digitization with authentic learning.

\section{Theme 7 (optional theme): Useful resources for learning}

Objective: At the end of the training stage, students will be able to create electronic materials that will help streamline the parent-child relationship. 
Detailing the contents: Starting from different contents that the children go through at school, the students, depending on the school cycle of which their children are part, will be given the task to make a lesson in order to facilitate the understanding of the notions by the child. For example, a parent whose child is a student in the first grade will be tasked with creating an interesting worksheet with exercises aimed at addition and subtraction operations in the 0-31 concentration with overrun. In this workshop, students will use the information acquired in the previous laboratory.

\section{Theme 8 (common theme): Online communication}

Objective: At the end of the training program, the beneficiaries will demonstrate the existence of online communication skills.

Content details: Beneficiaries will be trained to work with applications used for virtual communication: Whatsapp, Facebook Messinger, Skype, Zoom. In the laboratory activity, parents will learn how to install these applications, as well as how to use them. The benefits of using them are the following: the act of communication can take place in any corner of the world, multimedia files can be transferred, which can improve the parentchild relationship (pictures, videos with various activities of children / parents)

\section{Theme 9 (common theme): Digitization in the parenting profession}

Objective: At the end of the training program, parents will be able to analyze correctly and argued on the structure of SWOT the role of digitalization in the relationship with children.

Content details: In a workshop, parents will discover how to learn with the help of a digitized lesson: they will learn how to read different graphs and tables and starting from the previously learned contents, they will have the task to create a digitized lesson with the theme "The profession of parent"and to present to your own child.

This type of activity will help the parent to become more creative about technology, to create learning aids for himself and his child, as well as to be in constant contact with the child, as a result of the new technological skills he has.

Theme 10 (common theme): Streamlining the parent-child relationship in the technological age

Objective: At the end of the training program, parents will use strategies to streamline the parent-child relationship in the technological age.

Detailing the contents: in a plenary session, approaches will be presented to help the parent improve their relationship with their own child. These 
recommendations take into account: parents' proactivity for technology, accompanying the child in digital activities, attention to the model he instills as parents in technology, responsible online behavior, initiating discussions with children about their online activity. relationship

Theme 11 (optional theme): $n$ Remedial plan for improving the parent-child

Objective: At the end of the training program, parents will have a set of tools necessary to streamline the parent-child relationship.

Detailing the contents: Starting from the first optional topic, where in some laboratories, the peculiarities specific to the children's age, about the difficulties encountered in the parent-child relationship, as well as the lived experiences were discussed, a last optional one will be organized. laboratories, the trainer will establish a remedial plan to streamline the parent-child relationship, based on the use of digital resources.

\section{Discussions}

Through this research, it has been demonstrated that both the literature in the field of parental education and information resources in the virtual environment, present specific content in this field, in line with the society of the XXI century, a technological society in which effective parentchild relationship it also envisages their partnership in the use of technological resources.

It is found that the adaptation of the parent to the needs of the child, involves an adaptation to the technological society, in which technological resources are present everywhere, and can contribute to effective parentchild relationship.

A first strong point of this paper is the year of publication of specialized books, each of them being published after 2010. This fact demonstrates a growing concern for the presentation of content specific to the field of parental education.

A second strong point of the paper is the demonstration of a concordance between the contents specific to the field of parental education, which are treated in the literature and the contents specific to the same field, presented in the virtual environment. This concordance reveals a concern to provide accurate and relevant information regarding parental education, even in the online environment.

The results of the study may contribute to a deeper understanding of the education that parents need to benefit in the 21 st century. Based on these results, a training program dedicated to the parents of the 
technological society was designed, a program whose implementation can train among parents the skills needed to create a parent-child partnership based on the use of technology.

The limit of this study is represented by the use of a small number of specialized books in the field of parental education. For further research, several books will be analyzed, in order to provide a more complex overview of what parental education means.

\section{Conclusions}

Through this research, the following aspects related to parental education were demonstrated:

1. The specific elements of parental education are treated in the literature, in accordance with the changes of today's society, a technological society.

2. The virtual environment, although more difficult to control, provides an overview of parental education, similar to that presented through the literature. Following this finding, it is noted that parents can have access to valuable information on parental education, even online, provided that the source consulted is specialized.

Of the two hypotheses that formed the basis of the study, both were validated, concluding that parental education has become an increasingly theorized field in today's society, while demonstrating that through these theorizations, training programs can be achieved, through which parents to develop the skills necessary for effective parent-child relationship, mediated and te use of technology.

\section{References}

Bedard, N. (2015). Cum să ne comportăm cu copiii în funcție de temperamentu llor. Editura Orizonturi.

Chapman, G., \& Campbell, R. (2018). Cele cinci limbaje de iubire ale copiilor. Editura Curtea Vechea Publishing.

Chaudron, S., Gioia, R., D., Gemo, M. (2018). Young Children (0 - 8 ani) and Digital Technology. A qualitative study across Europe. JRC Science Hub. https://doi.org/10.2760/245671

Fengling, M., Breanne, E. W., Xianming, L., Zhenfen, H., Fen, X., \& Evans, A. (2018). Apologies repair children's trust: The mediating role of emotions. Journal of Experimental Child Psychology, 176, 1-12. https://doi.org/10.1016/i.jecp.2018.05.008

Ginott, H. G. (2018). Între părinte şi copil. Ghid de comunicare afectuoasă. Editura Humanitas. 
Gordon, T. (2014). Părintele eficient. Editura Trei.

Gottman, J. (2018). Parenting. Cum să creştem copii inteligenți emoțional. Editura Pagina de psihologie.

Kohn, A. (2013). Parenting necondiționat - de la recompense şi pedepse la iubire şi la înţelegere. Editura Multi Media Est Publishing.

Kohn, A. (2017). Mitul copilului răsfățat. Editura Herald.

Palladino, L. J. (2015). Copiii în epoca dependenței de tehnologie. Noile dispozitive digitale şi riscurile utilizării lor excesive. Editura Polirom.

Siegel, D. I., \& Bryson, T. P. (2019). Inteligența parentală. Disciplina dincolo de drame şi haos emoțional. Editura Pagina de psihologie.

Stan, L. (2016). Educația timpurie. Editura Polirom.

Sundus, M. (2018). The impact of using gadgets on children. Journal of Depression and Anxiety, 7(1). https://doi.org/10.4172/2167-1044.1000296

Xavier, S. (2015). Effects of electronic gadgetson the children: Mothers perspective. Kerala Sociologist, 43(2), 68-75.

Zakeri, H., \& Karimpour, M. (2011). Parenting Styles and Self-esteem. Social and Behavioral Sciences, 29, 758-761. https://doi.org/10.1016/j.sbspro.2011.11.302

Ziglar, Z. (2019). Putem creşte copii buni într-o lume negativă. Curtea Veche. 